\title{
Editorial
}

\section{Interferons and Viral Infections}

Interferons are among the most biologically active of known substances. They are proteins, the natural product of eukaryotic cells exposed to specific inducers, the best known of which is a virus infection. Interferons protect cells from the effect of virus replication by inhibiting the formation of new, in fectious virus particles. However, this protection is, generally speaking, only conferred on cells of the same species as that in which the interferon itself was produced. Although the antiviral effect was the first property of interferons to be recognised, subsequent studies have revealed that they have many other activities including the inhibition of cell growth and division, and modulation of the immune response, both humoral and cell mediated.

Of the three types of interferon, interferon $\alpha$ (leucocyte) and interferon $\beta$ (fibroblast) possess many similarities although they are antigenically distinct. Interferon $\gamma$ (immune) differs from interferon $\alpha$ and $\beta$ in many of its physical, chemical and biological activities as well as its antigenicity. Supplies of human interferons have been limited in the past because of the need for human cells for their production, and early preparations suffered the disadvantage of containing no more than $1 \%$ actual interferon. In the last few years recombinant DNA technology has permitted the production of human interferons by microorganisms, and improved techniques together with the use of monoclonal antibodies have resulted in preparations with a very high degree of purity. This applies not only to the three types of interferon but also to a number of the twenty or so subtypes of interferon $\alpha$ that are known to exist. Since such genetically engineered, highly purified interferons have been available for only a short time, much of the reported work with interferons in viral infections has been performed with interferons produced by leucocytes of the buffy coat of human blood or by . human fibroblasts. However, trials with the new interferon preparations have confirmed that the activity observed with the earlier, crude products was the result of the interferon they contained and not caused by impurities.

During influenza infections in humans the production of interferon parallels that of the clinical symptoms and virus excretion. By the time that antibodies are detected, interferon has virtually disappeared from the circulation (1). This suggests that interferons play an all important role in the limitation of, and recovery from, virus infections. Interferons are effective against practically all viruses and this makes them antivirals of great clinical potential. They are obviously indicated as replacement therapy in those who, for one reason or another, produce little or no interferon. This has been shown to occur in some children who are abnormally susceptible to upper respiratory tract infections (2) and also in some instances of fulminating hepatitis, when giving exogenous interferon appears to activate the patient's own interferon production (3). This latter observation may be an example of priming, in which the induction of cells pre-treated with a small quantity of interferon produces greater quantities of interferon than does the stimulation of cells without prior exposure.

As interferon's antiviral effect is mediated through the protection of non-infected cells and not by any direct action on the virus particle, interferon's prophylactic effect will probably be greater than its therapeutic action. Intradermal interferon prevents the 'take' of subsequently inoculated vaccinia virus (4), and interferon given intranasally before and after virus challenge protects volunteers against infection with rhinovirus (5-8) or coronavirus (9). Systemic interferon has been shown to reduce the incidence of herpetic lesions and the excretion of herpes virus following section of the trigeminal nerve in the treatment of tic douloureux (10). It also delays the excretion of cytomegalovirus (CMV) in the urine and reduces the incidence of CMV viraemia in renal transplant patients (11). More prolonged prophylaxis can also reduce the clinical manifestations of CMV infections in such patients (12).

In established acute viral infections the results have been less encouraging. In cases of herpes simplex virus infection leading to dendritic ulceration of the cornea, interferon alone has little effect, but in combination with wiping debridement (13), thermocautery (14) or trifluorothymidine (15) it is more effective than any of the treatments alone. Interferon does not influence the course of zoster in normal individuals, but in the immunosuppressed, where the appearance of endogenous interferon is delayed and the infection is more likely to become disseminated, interferon can reduce the incidence of serious complications and post-herpetic neuralgia. In addition it shortens the periods in the acute phase during which pain is experienced and new lesions appear (16). Similar but less conclusive results have been obtained following interferon treatment of varicella in children suffering from malignancies (17).

Interferon therapy has also been tried in chronic infections, notably those with hepatitis B virus. Quite dramatic reductions or elimination of the circulating markers of hepatitis B virus can be achieved with interferon (18). However, this may require repeated courses, with or without synthetic antivirals (19), 
and success is obtained in only a proportion of patients. Furthermore, this phenomenon is known to occur spontaneously in some untreated cases. Treatment of congenital rubella (20) and cytomegalovirus $(21,22)$ infections has not resulted in any consistent clinical improvement, although reduction in viral replication can be achieved.

Warts and the much rarer juvenile laryngeal papillomas result from infection with papillomaviruses. Warts respond to interferon applied locally $(23,24)$, while systemic interferon halts the progress of laryngeal papilloma and prevents its recurrence after surgical removal (25). It is by no means certain which of interferon's activities, antiviral, growth inhibition or immunomodulatory, is responsible for the effect observed in these cases.

The results summarized here represent very modest success for a substance which has been heralded as the ideal antiviral and recognised for over 25 years. Progress has been slow mainly because the limited supplies of interferon available until recently have restricted the number of trials. Furthermore, the optimal dosage, either prophylactically or therapeutically, has had to be determined by trial and error. For example it is now known that there is a critical concentration of interferon and frequency of administration below which intranasal interferon fails to protect against experimental rhinovirus infection (26) and that the beneficial effect of interferon in zoster in patients with malignancies is directly related to the amount given $(16,27)$. Unfortunately it has now become apparent that even the highly purified interferon is, itself, toxic. More than one million units given systemically results in fever, headache and malaise and if medication is continued it induces anorexia and fatigue. Such dosage also depresses the bone marrow and affects liver function. Even when given topically to the nasal mucosa, for any period of time greater than a few days, mild inflammatory changes occur which prevent its use for long-term prophylaxis (7).

However, much work needs to be done before interferon can be discarded as mainly of academic interest and of little clinical importance. Virtually no trials have been performed with interferon $\gamma$ or many of the interferon $\alpha$ subtypes, and it is possible that one or more of these may have a greater antiviral to toxic ratio than those already studied. It is not known if synergism exists between different types and subtypes of interferon. This would seem worthwhile exploring in view of the fact that the greatest success in therapy so far has been achieved with interferon in combination with synthetic antivirals.

\section{P. G. Higgins}

MRCCommon Cold Unit, Coombe Road, Salisbury, Wiltshire,
England SP2 8BW.

\section{References}

1. Baron, S., Dianzani, F.: General consideration of the interferon system. Texas Reports on Biology and Medicine $1977,35: 1-10$.

2. Isaacs, D., Clarke, J. R., Tyrrell, D. A. J., Webster, A. D. B., Valman, H. B.: Deficient production of leucocyte interferon (interferon- $\alpha$ ) in vitro and in vivo in children with recurrent respiratory tract infection. Lancet 1981, ii: $950-952$.

3. Levin, S., Hahn, T.: Interferon system in acute virus hepatitis. Lancet 1982, i: 592-594.

4. Scott, G. M., Cartwright, T., LeDu, G., Dicker, D.: Effect of human fibroblast interferon on vaccination in volunteers. Journal of Biological Standardization 1978, 6: 73-76.

5. Merigan, T. C., Reed, S. E., Hall, T. S., Tyrrell, D. A. J.: Inhibition of respiratory virus infection by locally applied interferon. Lancet 1973, i: 563-567.

6. Scott, G. M., Phillpotts, R. J., Wallace, J., Secher, D. S., Cantell, K., Tyrrell, D. A. J.: Purified interferon as protection against rhinovirus infection. British Medical Journal 1982, i: 1822-1825.

7. Samo, T. C., Greenberg, S. B., Couch, R. B., Quarles, J., Johnson, P. E., Hook, S., Harmon, M. W.: Efficacy and tolerance of intranasally applied recombinant leucocyte A interferon in normal volunteers. Journal of Infectious Diseases 1983, 148:535-542.

8. Hayden, F. G., Gwaltney, J. M.: Intranasal interferon $\alpha_{2}$ for prevention of rhinovirus infection and illness. Journal of Infectious Diseases 1983, 148: 543-550.

9. Higgins, P. G., Phillpotts, R. J., Scott, G. M., Wallace, J., Bernhardt, L. L., Tyrrell, D. A. J.: Intranasal interferon as protection against experimental respiratory coronavirus infection in volunteers. Antimicrobial Agents and Chemotherapy 1983, 24:713-715.

10. Pazin, G. J., Armstrong, J. A., Lam, M. T., Tarr, G. C., Jannetta, P. J., Ho, M.: Prevention of reactivated herpes simplex infection by human leukocyte interferon after operation on the trigeminal root. New England Journal of Medicine 1979, 301: 225-230.

11. Cheeseman, S. H., Rubin, R. H., Stewart, J. A., TolkoffRubin, N. E., Cosimi, A. B., Cantell, K., Gilbert, J., Winkle, S., Herrin, J. T., Black, P. H., Russell, P. S., Hirsch, M.S.: Controlled clinical trial of prophylactic human-leukocyte interferon in renal transplantation. Effects on cytomegalovirus and herpes simplex virus infections. New England Journal of Medicine 1979, 300: 1345-1349.

12. Hirsch, M. S., Schooley, R. T., Cosimi, A. B., Russell, P. S., Delmonico, F. L., Tolkoff-Rubin, N. E., Herrin, J. T., Cantell, K., Farrell, M. L., Rota, T. R., Rubin, R. H.: Effects of interferon-alpha on cytomegalovirus reactivation syndromes in renal transplant recipients. New England Journal of Medicine 1983, 308: 14891493.

13. Jones, B. R., Coster, D. J., Faloon, M. G., Cantell, K.: Topical therapy of ulcerative herpectic keratitis with human interferon. Lancet 1976, ii: 128.

14. Sundmacher, R., Neumann-Haefelin, D., Cantell, K.: Successful treatment of dendritic keratitis with human leucocyte interferon - a controlled clinical study. Graefes Archiv für Klinische und Experimentelle Opthalmologie 1976, 201: 39-45.

15. Sundmacher, R., Cantell, K., Neumann-Haefelin, D.: Combination therapy of dendritic keratitis with trifluorothymidine and interferon. Lancet 1978, ii: 687 .

16. Merigan, T. C., Rand, K. H., Pollard, R. B., Abdallah, P. S., Jordan, G. W., Fried, R. P.: Human leukocyte interferon for the treatment of herpes zoster in patients with cancer. New England Journal of Medicine 1978, 298: $981-987$. 
17. Arvin, A. M., Kushner, J. H., Feldman, S., Baehner, R. L., Hammond, D., Merigan, T. C.: Human leukocyte interferon for the treatment of varicella in children with cancer. New England Journal of Medicine 1982 , 306: 761-765.

18. Greenberg, H. B., Pollard, R. B., Lutwick, L. I., Gregory, P. B., Robinson, W. S., Merigan, T. C.: Effect of human leukocyte interferon on hepatitis $B$ virus infection in patients with chronic active hepatitis. New England Journal of Medicine 1976, 295: 517-522.

19. Scullard, G. H., Pollard, R. B., Smith, J. L., Sacks, S. L., Gregory, P. B., Robinson, W. S., Merigan, T. C.: Antiviral treatment of chronic hepatitis $B$ virus infection. 1. Changes in viral markers with interferon combined with adenine arabinoside. Journal of Infectious Diseases 1981, 143: 772-783.

20. Arvin, A. M., Schmidt, N. J., Cantell, K., Merigan, T. C.: Alpha interferon administration to infants with congential rubella. Antimicrobial Agents and Chemotherapy 1982, 21: 259-261.

21. Emödj, G., O'Reilly, R., Müller, A., Everson, L. K., Binswanger, U., Just, M.: Effect of human exogenous leukocyte interferon in cytomegalovirus infections. Journal of Infectious Diseases 1976, 133: A199-204.
22. Arvin, A. M., Yeager, A. S., Merigan, T. C.: Effect of leukocyte interferon on urinary excretion of cytomegalovirus by infants. Journal of Infectious Diseases 1976, 133: A205-210.

23. Ikić, D., Bosnić, N., Smerdel, S., Jušić, D., Šooš, E., Delimar, N.: Double blind clinical study with human leukocyte interferon in the therapy of condylomata acuminata. In: D. Ikic (ed.): Proceedings of a Symposium on Clinical Use of Interferon. Yugoslav Academy of Sciences and Arts, Zagreb, 1975, p. 229-233.

24. Scott, G. M., Csonka, G. W.: Effect of injections of small doses of human fibroblast interferon into genital warts: a pilot study. British Journal of Venereal Disease 1979,$55 ; 442-445$.

25. Haglund, S., Lundquist, P. G., Cantell, K., Strander, H.: Interferon therapy in juvenile laryngeal papillomatosis. Atchives of Otolaryngology 1981, 107: 327-332.

26. Phillpotts, R. J., Scott, G. M., Higgins, P. G., Wallace, J., Tyrrell, D. A.J., Gauci, C. L.: An effective dosage regimen for prophylaxis against thinovirus infection by intranasal administration of HuIFN- $\alpha_{2}$. Antiviral Research $1983,3: 121-136$

27. Merigan, T. C., Gallagher, J. G., Pollard, R. B., Arvin, A. M.: Short-course human leukocyte interferon in treatment of herpes zoster in patients with cancer. Antimicrobial Agents and Chemotherapy 1981, 19:193195. 